\title{
Solutions and Techniques for Conservative and Effective Use of Arable Lands in the Somesan Plateau
}

\author{
Adrian Ioan POP*, Teodor RUSU, Ileana BOGDAN, Paula Ioana MORARU, Bogdan Matei DUDA, Camelia \\ Liliana COSTE, Tudor SALAGEAN
}

Faculty of Agriculture, University of Agricultural Sciences and Veterinary Medicine Cluj-Napoca

3-5, Mănăștur Street, 400372, Cluj-Napoca, Romania

* corresponding author: aipop21@yahoo.com

Bulletin USAMV series Agriculture 71(1-2)/2014

Print ISSN 1843-5246; Electronic ISSN 1843-5386

DOI 10.15835/buasvmcn-agr: 10233

\begin{abstract}
The results presented in this paper were obtained in the experimental fields of agrotechnics discipline from the Jucu region in Cluj, on an argic-stagnic Phaoezem soil, with a humus content of $3.8 \%$ and a $\mathrm{pH}$ of 6.5 . The soil tillage system made using plow, chisel, paraplow and direct sowing affects the quality of soil's structure by modifying the structure of macroagregate fractions and the percentage of microaggregates, identifiable on a 0-10 cm depth. In the first $30 \mathrm{~cm}$ the best degree of loosening was recorded on soils which had been plowed, where bulk density did not exceed $1.28 \mathrm{~g} / \mathrm{cm} 3$, and the lowest loosening on soils sown directly where the values ranged arownd $1.43 \mathrm{~g} / \mathrm{cm} 3$. In variants tilled with chisel and paraplow the bulk density values are practically equal $1.27-1.28 \mathrm{~g} / \mathrm{cm} 3$. Soil resistance to penetration is significantly influenced on all depths. The highest value of the three cultures determined on the depth of $0-10 \mathrm{~cm}$ is recorded for direct seeding with values of $980 \mathrm{kPa}$, followed by the unconventional variants tilled with paraplow and chisel of 767-877 $\mathrm{kPa}$. Wheat production in the experimenal yers was influenced by the tillage system and rainfall so that in Somes Plateau's conditions, productions ranged from $3887 \mathrm{~kg} / \mathrm{ha}$ in the variant worked with plow and $3465 \mathrm{~kg} /$ ha for the direct sown variant. In the case of unconventional tillage variants, using chisel and paraplow, the productions were similar. The tillage system for the variants made using plow respectively chisel, paraplow and direct sow ensures soybean's productions between $2310 \mathrm{~kg} / \mathrm{ha}$ for the plowing variant, $2142 \mathrm{~kg} / \mathrm{ha}$ for direct sowing variant and variants worked with chisel and paraplow ensure production of $2176-2234 \mathrm{~kg} / \mathrm{ha}$. Tillage systems with chisel and paraplow registered on maize production of 94.4-97.2\% from the control variant tilled with plow. The difference in minus for the variants with chisel and paraplow is primarily attributed to the higher degree of weeds at the two ways of soil tillage. In the variant of direct sowing is only carried out $89.3 \%$ of the production of the control variant with plow, which calls into question the economic efficiency of this mode of tillage for maize crops in the conditions of Somesan Plateau. After the economic analysis of the three variants it can be found that in the case of wheat crops is achieved a profit of $2-8 \%$ and one of $4-12 \%$ for soybean, this profit made per unit area is motivated since energy consumptions is more reduced to three modes of tillage. For the maize crops the profits are lower in all three variants up to $8 \%$ as the number of plants per unit area is lower due to the uneven emergence.
\end{abstract}

Keywords: conservative systems, arable land, crop rotation, production, economic efficiency.

\section{INTRODUCTION}

Somesan Plateau fits from a geographical point of view in the northwest of the country, from the foothills of Gilau mountains (S) to the contact with the Western Hills (NV), from the peak of Breaza (NE), to the lane formed by the Small Somes and Big Somes (E) and Almas - Agrij depression (V) (Romanian Geography Vol. III, 1987).

Somesan Plateau's landscape is much more energetic and active with intense slope processes triggered in time. The relief prints significant differences throughout the area, here being the highest contrasts of stationary factors due to very kneaded landscape and varied lithological substrate. In general, any changes in relief entails fundamental changes in all local factors forming interdependencies in the topo-climate, in the soil characteristics and vegetation physiognomy (Grigor, 2001). 
From a climatic point of view the annual average temperature is $7.8^{\circ} \mathrm{C}$ with the highest average in August and lowest in January and December. Atmospheric precipitation presented in the analyzed period of time, showed an annual average value of about $700 \mathrm{~mm}$, the highest amount of rainfall being specific to the warm season of the year (May-August) and the lowest occurs in the winter months (January-February). One of the main features of the rainfall regime of Somesan Plateau represents it's great variability over time manifested both by large quantities of fallen water oscillations as well as it's distribution in time. In terms of land distribution, Somesan Plateau soils are characterized by the predominance of Luvisoils (preluvisoils and luvisols), (Bunescu et al., 2005).

The natural conditions are favorable for the cultivation of a large number of plants, especially cereals such as winter wheat, maize, barley, rye and oats, being grown in the valleys, lowlands, low hills up to $60 \%$ of agricultural land and some perennial legumes like alfalfa and clover. On smaller areas are cultivated potato, sunflower, sugar beet and soybean.

The research conducted to date have shown the advantages of using these technologies in the long term, resulting in reduced soil erosion, improved infiltration and retention of water in soil, reduced costs, reduced labor and increased production (Govaerts et al., 2005; Sayre et al., 2007; Lichter et al., 2008). From research carried out in parallel of classical system of working the soil and no-till for 10 years on a clay-sandy soil (Curaqueo et al., 2011) observed that soil bulk density and porosity were not influenced significantly, which gave good values to the larger conservative system of work and increased with depth, results confirmed by Martinez et al. (2008) and Roscoe and Burman (2003).

In general it is clear that a soil worked many consecutive years using no-tillage system leads to increased bulk density due to the traffic of sowing machines (Botta et al., 2009) and at the same time decreases soil porosity, a phenomenon associated with reduced reserve 02 required for heterotrophic microbial decomposition. Use of conservative tillage contributes to the reduction of greenhouse gas (GHG) and global warming, in fixing carbon in the soil and produce time and energy savings up to $40 \%$ (FAO, 2004; Franchini et al., 2007).
Knowledge about soil suitability or favorability for different methods of work represents one of the most important conditions for effective use of agricultural lands located on slopes by promoting sustainable agriculture, economically efficient and environmental protective. Since conventional agricultural production systems caused soil degradation in many countries, the land management technologies on crop rotations, tillage and fertilization systems, pedoameliorative work and crop protection systems must be adapted to the protection of soil and water and in areas vulnerable to land degradation are necessary soil conservation works (Sandoiu, 1999; Lazureanu et al., 1997; Gus et al., 2004).

Currently, conservative works on slopes define highly varied processes from direct sowing (no-tillage) to deep loosening of the soil without turning the furrow. Between the two extremes are found variants as: reduced works (classic streamlined), minimum works (with coverage below $30 \%$, minimum tillage), minimum vegetal mulch works (covering over $30 \%$, mulch tillage), sown on ridges (ridge tillage), works made partially or in strip (strip till, zone till), protective layer works (cover crops, catch crops), ehich emphasize the specific terminology that defines that method applied to a point in a certain area according to local specificity (Horn and Arvidsson, 2000; Moroizumi and Horino, 2002; Gus and Rusu, 2003).

Conservation of soil fertility involves the application of a work system in order to optimize the cultural requirements of the plant by using several indicators of soil properties (Rusu, 2001; Mark et al., 2004; Feiza et al., 2005; Jitareanu et al., 2006).

Minimum tillage systems has as main characteristic the conservation of soil, maintaining a proper ratio of soil organic matter and improving the activity of microorganisms (Ulich et al., 2006; Sarauskis et al., 2009; Teixeira et al., 2010).

\section{MATERIALS AND METHODS}

The purpose of this paper is to applytechniques for conservative use of arable land, given a number of issues on land suitability, structure of type of land use, efficient technologies and of soil tillage cultivation by expanding the areas in which one can use these systems, sometimes being limited by soil characteristics, lanscape, rainfall and crop structure of the region. The results presented 
in this paper were obtained in the experimental fields of agrotechnics discipline from the Jucu region in Cluj, on an argic-stagnic Phaoezem soil, with a humus content of $3.8 \%$ and a $\mathrm{pH}$ of 6.5 . From a climateric point of view, the hilly area where the experiments took place is characterised by medium annual precipitations between 550$650 \mathrm{~mm}$. The thermal regime of the area is characterised by annual average temperatures between $8,0-8.2^{\circ} \mathrm{C}$.

The experimental field consisted in a bifactorial experience AxB-R type: $4 \times 3-3$, placed by the subdivided parcels method, for wheat, soybeans and maize crops.

Experimental factors: Factor $\boldsymbol{A}$ - Soil tillage: $a_{1}$-worked with reversible plow; $a_{2}$ - worked with chisel; $\mathrm{a}_{3}-$ worked with paraplow; $\mathrm{a}_{4}$ - direct sowing; Factor $\boldsymbol{B}$ - Crop rotation: $\mathrm{b}_{1}$ - soybean; $\mathrm{b}_{2}$ wheat; $b_{3}$ - maize.

\section{RESULTS AND DISCUSSIONS}

Soil quality is given by the chemical (Tab.2) and physical (Tab.3) characteristics, which enclose the soil in the group of mesobasic to eubasic with a V\% in the the first $50 \mathrm{~cm}$ ranging between 74.04 - 85.11\%, noting significant proportion of the sum of exchangeble bases which reach values between 25.84 - $31.16 \mathrm{me} / 100 \mathrm{~g}$ soil. Corresponding saturation ensures adequate cation exchange capacity values between $34.90-36.61 \mathrm{mg} / 100 \mathrm{~g}$ soil, which gives it a good buffering capacity and a good storage of elements of fertility.

Good fertility status is given also by the content of humus which has values of $5.33-5.57 \%$ in the first $50 \mathrm{~cm}$ providing an organic carbon content of

Tab. 1. Thermal and pluviometric regime (2006-2012)

\begin{tabular}{lcc}
\hline Agricultural year (2006-2012) & Annual average value $\left({ }^{\circ} \mathrm{C}\right)$ & $\Sigma(\mathrm{mm})$ annual rainfall \\
\hline $2006-2007$ & 10.4 & 602.0 \\
\hline $2007-2008$ & 10.1 & 463.1 \\
\hline $2008-2009$ & 9.5 & 560.4 \\
\hline $2009-2010$ & 9.2 & 475.6 \\
\hline $2010-2011$ & 9.7 & 397.2 \\
\hline Annual average & 9.4 & 406.7 \\
\hline Multiannual average & 9.7 & 484.0 \\
\hline
\end{tabular}

Tab. 2. The chemical features of stagnic argic phaoezem in the experimental field of Jucu, Cluj county

\begin{tabular}{lccccc}
\hline Horison & $\mathrm{Ap}$ & $\mathrm{Am}$ & $\mathrm{A} / \mathrm{Bw}$ & $\mathrm{Btw}$ & $\mathrm{B} / \mathrm{C}$ \\
Depth -cm- & $0-20$ & $20-40$ & $40-60$ & $80-100$ & $150-160$ \\
\hline $\mathrm{pH}\left(\mathrm{H}_{2} \mathrm{O}\right)($ water $\mathrm{pH})$ & 5.95 & 6.30 & 6.73 & 7.11 & 7.88 \\
\hline $\mathrm{Ca} \mathrm{CO}_{3} \%$ & 0.00 & 0.00 & 0.00 & 0.00 & 0.40 \\
\hline$\%$ Humus & 5.57 & 5.33 & 3.27 & 0.00 & 0.00 \\
\hline Organic C $\%$ & 3.23 & 3.09 & 1.89 & - & - \\
\hline $\mathrm{t} /$ ha Humus reserve & 135.91 & 136.45 & 88.29 & - & - \\
\hline$\%$ N total & 0.195 & 0.207 & 0.192 & 0.049 & 0.026 \\
\hline $\mathrm{C}: \mathrm{N}$ & 16.56 & 14.93 & 9.84 & - & - \\
\hline Nitrogen index & 4.12 & 4.24 & 2.78 & - & - \\
\hline $\mathrm{P}_{2} \mathrm{O}_{5} \mathrm{mg} / 100 \mathrm{~g}$ sol $(\mathrm{ppm} \mathrm{P)}$ & $4.14(18.00)$ & $3.68(16.00)$ & $3.45(15.00)$ & $0.92(4.00)$ & - \\
\hline $\mathrm{K}_{2} \mathrm{O} \mathrm{mg} / 100 \mathrm{~g}$ sol $(\mathrm{ppm} \mathrm{K})$ & $18.07(149.98)$ & $17.11(142.01)$ & $16.14(133.96)$ & $18.55(153.96)$ & - \\
\hline $\mathrm{SB} \mathrm{me} / 100 \mathrm{~g}$ sol & 25.84 & 28.96 & 31.16 & - & - \\
\hline $\mathrm{SH} \mathrm{me} / 100 \mathrm{~g}$ sol & 9.06 & 7.37 & 5.45 & - & - \\
\hline $\mathrm{T} \mathrm{me} / 100 \mathrm{~g}$ sol & 34.90 & 36.33 & 36.61 & - & - \\
\hline $\mathrm{V} \%$ & 74.04 & 79.71 & 85.11 & - & - \\
\hline
\end{tabular}


Tab. 3. The physical features of stagnic argic Phaoezem in the experimental field of Jucu, Cluj county

\begin{tabular}{lccccc}
\hline Horison, Depth-cm- & Ap & Am & A/Bw & Btw & B/C \\
& $0-20$ & $20-40$ & $40-60$ & $80-100$ & $150-160$ \\
\hline Brutish sand $(2-0,2 \mathrm{~mm}) \%$ & 1.24 & 0.56 & 0.41 & 0.28 & 1.02 \\
\hline Fine sand $(0,2-0,02 \mathrm{~mm}) \%$ & 20.21 & 22.64 & 21.09 & 20.14 & 20.48 \\
\hline Dust I $(0,02-0,01 \mathrm{~mm}) \%$ & 14.50 & 15.00 & 12.75 & 10.80 & 9.10 \\
\hline Dust II $(0,01-0,002 \mathrm{~mm}) \%$ & 20.70 & 18.80 & 20.15 & 18.52 & 14.65 \\
\hline Clay $(<0,002 \mathrm{~mm} \% \%$ & 43.33 & 43.00 & 45.60 & 50.26 & 54.75 \\
\hline Texture & LA & LA & LA & A & A \\
\hline Hy\% & 9.80 & 10.65 & 10.80 & 13.50 & 13.85 \\
\hline CO \% $\left(0,05+0,350 \mathrm{~A}^{*}\right)$ & 15.22 & 15.10 & 16.01 & 17.64 & 19.21 \\
\hline CC \% $\left(21,2+0,0626 \mathrm{~A}^{*}\right)$ & 23.91 & 23.89 & 24.05 & 24.34 & 24.62 \\
\hline CAU $(\mathrm{CC}-\mathrm{CO} \%$ & 8.69 & 8.79 & 8.04 & 6.70 & 5.41 \\
\hline DA g/cm ${ }^{3}$ & 1.22 & 1.28 & 1.35 & 1.41 & 1.45 \\
\hline PT $=100(1-D A: 2,70) \%$ & 54.81 & 52.59 & 50.00 & 47.78 & 46.30 \\
\hline PA (PT-CCv)\% & 25.63 & 22.01 & 17.53 & 13.46 & 10.60 \\
\hline Resistance to penetration $\left(\mathrm{KPa} / \mathrm{cm}^{2}\right)$ & 345.21 & 521.42 & - & - & - \\
\hline
\end{tabular}

$\mathrm{A}^{*}$ - clay content $(\%)$

3.09-3.23, respectively a reserve of humus 272.36 t/ha.

The content of nutrients differ on the soil profile, being properly a good supply of potassium and middle one of phosphorus. In terms of chemical elements the only interventions that require completion are the phosphorus reserves and maintaining the current limits of the $\mathrm{pH}$ value.

Physical properties of the argic-stagnic Phaoezem, positively complement chemical characteristics on physical aspect, texture is clayloam in the first $80 \mathrm{~cm}$ with a relatively high clay content ranging from 43.00-45.60\%, which give specific features to the fine textured soils.

What is the noteworthy is the participation of all particle size fractions in soil structure of physical composition with a weight greater than $21 \%$ of fine sand and approx. $32-34 \%$ of dust. The clay content can be the element that limits the expansion of minimum tillage systems, but only on soils lacking soil texture and organic matter. The structure is glomerular with a good hydric stability, which gives it moderate resistance when carrying out works and an alternating negative effect imprinted to the clayey texture.

Hydrophysical indices, mainly the coefficient of wilting, field capacity and water capacity are specific for phaoezem soils, providing due to the high values of the wilting coefficient, medium values of the mean field capacity and water capacity, good air-water relationship favorable both for microorganisms and plant cultivation. Bulk density with small towards medium values on arable layers and in some years even very small range between $1.20-1.22 \mathrm{~g} / \mathrm{cm} 3$, adversely affect germination and emergence of maize and even soybean seeds by a lack of moisture.

Values of $1.28-1.35 \mathrm{~g} / \mathrm{cm} 3$ on $20-60 \mathrm{~cm}$ depth are beneficial to microorganisms activity and development of crop's root system. Soil porosity has optimal values with limits between 50.00$52.59 \%$ on $20-60 \mathrm{~cm}$ depth and higher values in the first $20 \mathrm{~cm}$, but not exceeding 55\%.

Plant cultivation in general and tillage system practiced, particularly soil structure involves two opposing processes: of destruction and recovery. Capacity of the system to favor one or another of these processes cause deterioration or improvement of soil structure. The soil tillage system made using plow, chisel, paraplow and direct sowing affects the quality of soil's structure by modifying the structure of the macroagregate fractions and the percentage of microaggregates, identifiable on $0-10 \mathrm{~cm}$ depth. Compared with the control, variant in which the land was plowed, conservative systems variants using chisel and paraplow, makes the percentages of stable aggregates to be maintained or increased. 
At paraplow is recorded an increase of $1.2 \%$ of microaggregates on the depth of $0-10 \mathrm{~cm}$, explained by the fact that small particles without particular stability of $3-5 \mathrm{~mm}$ size fraction 2 , were transported on opened tracks by paraplow towards depth. Regarding the variant sowed directly is confirmed a decrease in quality of the structure since the percentage of hydrostable macroagregates reach $68.5 \%$ compared with $74.6 \%$ in the plowed version and $76.2 \%$ in the variant worked with chisel. The degree of loosening determined at the end of the production cycle confirmed the differences in relation to the way of working of the soil and the depth of the soil sampling.

Data analysis (Tab.4) confirms three distinct situations: the first variant, when the soil was worked using plow; second, when the soil was worked using chisel and paraplow and the third, when the soil was sown directly. In the first $30 \mathrm{~cm}$ the degree at the best loosening was recorded at the plowed field where bulk density did not exceed $1.28 \mathrm{~g} / \mathrm{cm} 3$, and the lowest loosening on the field sown directly where the values ranged around 1.43 $\mathrm{g} / \mathrm{cm} 3$. Obvious differences in terms of loosening are recorded in the first $10 \mathrm{~cm}$ in which the direct seeding variant has bulk density values of $1.35 \mathrm{~g} /$ $\mathrm{cm} 3$ and plowed variant of $1.22 \mathrm{~g} / \mathrm{cm} 3$. In variants worked with chisel and paraplow, bulk density values are practically equal 1.27-1.28 $\mathrm{g} / \mathrm{cm} 3$. Differences also appear on the depth of $10-20 \mathrm{~cm}$ with the understanding that the best loosening was recorded at variant worked with plow, followed by the variant worked with paraplow, chisel and direct sowing. Humus content on the $0-10 \mathrm{~cm}$ depth, between the four types of tillage, confirms in the case of direct seeding the highest values of $5.18 \%$, followed by the variant with paraplow of $5.11 \%, 5.05 \%$ for chisel and lowest in the classical variant $4.89 \%$.

Influence of tillage systems on weed growth (Fig.1) reveals the degree of weeds at three diffe-

Tab. 4. Influence of tillage systems on agrophysical and agrochemical indicators of the soil

\begin{tabular}{cccccc}
\hline Indicators & Depth $(\mathrm{cm})$ & $\begin{array}{c}\text { Reversible } \\
\text { plow }\end{array}$ & Chisel & Paraplow & Direct sowing \\
\hline \multirow{2}{*}{ Degree of } & $0-10$ & 74.6 & 76.2 & 75.8 & 68.5 \\
hydrostability \% & $10-20$ & 77.0 & 77.8 & 78.3 & 70.6 \\
& $20-30$ & 75.4 & 78.2 & 78.6 & 72.3 \\
\hline \multirow{2}{*}{ Bulk density } & $0-10$ & 1.22 & 1.28 & 1.27 & 1.35 \\
g/cm & $10-20$ & 1.26 & 1.36 & 1.33 & 1.39 \\
& $20-30$ & 1.28 & 1.39 & 1.40 & 1.43 \\
\hline & $0-10$ & 4.89 & 5.05 & 5.11 & 5.18 \\
Humus content \% & $10-20$ & 4.12 & 4.93 & 4.85 & 4.56 \\
& $20-30$ & 3.52 & 3.68 & 3.74 & 3.32 \\
\hline
\end{tabular}

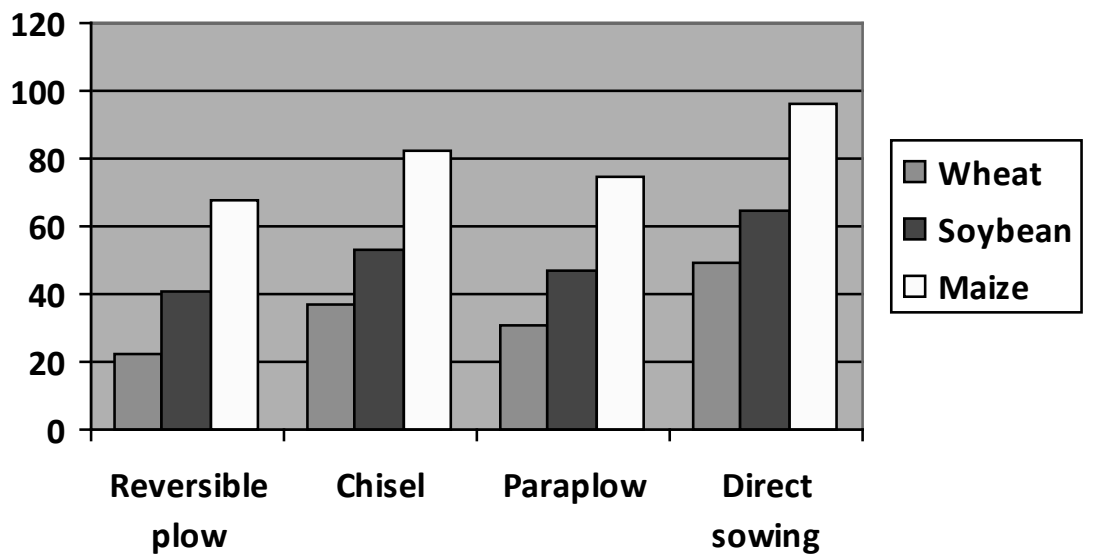

Fig. 1. Weed growth in wheat, soybean and maize cultures according to the tillage system 
rent cultures depending on the tillage system, as compared to the control variant with plow, in which were identified 131 weeds $/ \mathrm{m}^{2}$, in the variants work with paraplow and chisel the number of weeds $/ \mathrm{m}^{2}$ is between $153-172$ and in the version with direct sowing weeding degree is the highest reaching 210 weeds $/ \mathrm{m}^{2}$.

Wheat production in the experimenal yers was influenced by the tillage system and rainfall so that in Somes Plateau's conditions, productions ranged from $3887 \mathrm{~kg} / \mathrm{ha}$ in the variant worked with plow and $3465 \mathrm{~kg} / \mathrm{ha}$ for the direct sown variant. In the case of unconventional tillage variants, using chisel and paraplow, the productions were similar.

Variant worked with paraplow represents an alternative method for the plowed variant, except that the $134 \mathrm{~kg}$ of wheat in minus is not a difference statistically assured. When looking at the classification in order of production levels, the plow variant lies first and direct sowing in stubble variant comes last.

Taking into account the production potential of the land on which is cultivated, for winter wheat culture, using the variant with paraplow could be an alternative for the conventional plowed variant, knowing the advantages of conventional systems to reduce costs and especially those caused by the consumption of diesel. The impact of unconventional soil tillage systems on yield is compensated by the advantages to be recorded in soil conservation and crop quality.

The variant with direct seeding conducted a minus of $10.9 \%$, which means about $422 \mathrm{~kg} /$ ha wheat.

Soil tillage system (Tab.5) from variants a1-a4 with plowing respectively soil worked with chisel, paraplow and direct sowing ensures productions of soybean between $2310 \mathrm{~kg} / \mathrm{ha}$ in variant with plowing, $2142 \mathrm{~kg} / \mathrm{ha}$ for the variant with directly sowing and for the variants worked with chisel and paraplow productions between 2176-2234 $\mathrm{kg} / \mathrm{ha}$.

From our point of view we attribute these differences to insufficient soil loosening compared to the variant with plowed soil, which influenced mainly the raising of nodules and root system better development. Analysis on the results of production at maize crops highlights limits between $6126-6863 \mathrm{~kg} / \mathrm{ha}$ maize grains regardless of tillage system (Tab.5).

Tab. 5. Influence of tillage systems on production and economic efficiency

\begin{tabular}{|c|c|c|c|c|c|c|c|c|c|}
\hline \multirow{3}{*}{ Working variant } & \multicolumn{3}{|c|}{ Wheat } & \multicolumn{3}{|c|}{ Soybean } & \multicolumn{3}{|c|}{ Maize } \\
\hline & \multicolumn{2}{|c|}{ Production } & \multirow{2}{*}{$\begin{array}{c}\text { Profit } \\
\%\end{array}$} & \multicolumn{2}{|c|}{ Production } & \multirow{2}{*}{$\begin{array}{c}\text { Profit } \\
\%\end{array}$} & \multicolumn{2}{|c|}{ Production } & \multirow{2}{*}{$\begin{array}{c}\text { Profit } \\
\%\end{array}$} \\
\hline & (kg/ha) & $\%$ & & (kg/ha) & $\%$ & & (kg/ha) & $\%$ & \\
\hline Reversible plow & $3887^{c}$ & 100 & 100 & $2310^{c}$ & 100 & 100 & $6863^{c}$ & 100 & 100 \\
\hline Chisel & $3684^{0}$ & 94.8 & 102 & $2176^{0}$ & 94.2 & 104 & $6479^{00}$ & 94.4 & 92 \\
\hline Paraplow & $3753^{\text {ins }}$ & 96.6 & 105 & $2234^{\text {ins }}$ & 96.7 & 107 & $6672 \mathrm{i}^{\mathrm{ns}}$ & 97.2 & 95 \\
\hline \multirow[t]{2}{*}{ Direct sowing } & $3465^{00}$ & 89.1 & 108 & $2142^{0}$ & 92.7 & 112 & $6126^{000}$ & 89.3 & 97 \\
\hline & \multicolumn{3}{|c|}{$\begin{array}{c}\text { DL(p 5\%) }=177 \mathrm{Kg} / \mathrm{ha} \\
\operatorname{DL}(\text { p } 1 \%)=268 \mathrm{Kg} / \mathrm{ha} \\
\text { DL(p 0.1\%) }=430 \mathrm{Kg} / \mathrm{ha}\end{array}$} & \multicolumn{3}{|c|}{$\begin{array}{c}\text { DL(p 5\%) }=130 \mathrm{Kg} / \mathrm{ha} \\
\mathrm{DL}(\mathrm{p} 1 \%)=197 \mathrm{Kg} / \mathrm{ha} \\
\text { DL(p 0.1\%) }=316 \mathrm{Kg} / \mathrm{ha}\end{array}$} & \multicolumn{3}{|c|}{$\begin{array}{c}\text { DL(p 5\%) }=209 \mathrm{Kg} / \mathrm{ha} \\
\operatorname{DL}(\mathrm{p} 1 \%)=316 \mathrm{Kg} / \mathrm{ha} \\
\operatorname{DL}(\mathrm{p} 0.1 \%)=508 \mathrm{Kg} / \mathrm{ha}\end{array}$} \\
\hline
\end{tabular}

Tab. 6. Soil resistance to penetration $(\mathrm{kPa})$

\begin{tabular}{|c|c|c|c|c|c|c|c|c|c|c|c|c|}
\hline Variant & \multicolumn{3}{|c|}{ Reversible plow } & \multicolumn{3}{c|}{ Chisel } & \multicolumn{3}{c|}{ Paraplow } & \multicolumn{3}{c|}{ Direct sowing } \\
\hline $\begin{array}{c}\text { Depth } \\
(\mathrm{cm})\end{array}$ & Wheat & Soy & Maize & Wheat & Soy & Maize & Wheat & Soy & Maize & Wheat & Soy & Maize \\
\hline $0-10$ & 672 & 583 & 854 & 887 & 748 & 996 & 773 & 615 & 913 & 964 & 835 & 1142 \\
\hline $10-20$ & 751 & 613 & 995 & 894 & 849 & 1202 & 805 & 747 & 1108 & 1106 & 954 & 1374 \\
\hline $20-30$ & 796 & 677 & 1153 & 953 & 978 & 1289 & 832 & 796 & 1210 & 1255 & 1169 & 1471 \\
\hline $30-40$ & 853 & 875 & 1479 & 1283 & 1012 & 1465 & 996 & 931 & 1502 & 1446 & 1358 & 1673 \\
\hline $40-50$ & 1151 & 1083 & 1645 & 1657 & 1074 & 1736 & 1492 & 1098 & 1710 & 1759 & 1423 & 1890 \\
\hline
\end{tabular}


Comparing productions we notice a maximum amount of $6863 \mathrm{~kg} / \mathrm{ha}$ in the field where work was carried out using the plow at a depth of $28-30 \mathrm{~cm}$. We assign the explanation to the positive effects of the plowing on the growth regarding water conservation in soil, reducing the degree of weeds and favorising microorganisms activity by heating the soil early, in the growing season favouring a better vegetation starting of crops.

Tillage systems with chisel and paraplow recorded production of only $94.4-97.2 \%$ of the control variant with plow. The difference in minus at the variants with paraplow and chisel we primarily assign to the higher degree of weeds at the two ways of soil tillage.

In the direct sowing variant is only carried out $89.3 \%$ of the control variant with plow, which calls into question the economic efficiency of this mode of soil tillage for maize crops under the condition of the Somesan Plateau.

After the economic analysis of the three variants it can be found that in the case of wheat crops is achieved a profit of $2-8 \%$ and one of $4-12 \%$ for soybean, this profit made per unit area is motivated since energy consumptions is more reduced to three modes of tillage. For the maize crops the profits are lower in all three variants up to $8 \%$ as the number of plants per unit area is lower due to the uneven emergence.

Soil resistance to penetration is significantly influenced on all depths. The highest value of the three cultures determined on the depth of $0-10$ $\mathrm{cm}$ is recorded for direct seeding with values of $980 \mathrm{kPa}$, followed by the unconventional variants tilled with paraplow and chisel of 767-877 $\mathrm{kPa}$. In the variant worked with plow values are $703 \mathrm{kPa}$, confirming a better loosening and development of the root system of crops in the arable horizon.

\section{CONCLUSION}

Research conducted on conservative soils give solutions and techniques and effective use of arable land, finding a positive influence of their application by the effects of soil properties and production conservation insured. The application of works in a rotation of wheat, soybeans and maize crops caused improvement of physical, hydro-physical, rebuilt of soil structure and increased water permeability.

The soil tillage system made using plow, chisel, paraplow and direct sowing affects the quality of soil's structure by modifying the structure of the macroagregate fractions and the percentage of microaggregates, identifiable on $0-10 \mathrm{~cm}$ depth. Compared with the control variant, one in which the land was plowed, the variants with chisel and paraplow conservative systems, the percentages of stable aggregates is maintained or increased by $1.2-1.6 \%$. In the case of direct sowing variant is confirmed a decrease in the quality of the structure since the rate of hydrostable macroagregates reached $68.5 \%$ compared to $74.6 \%$ at the variant with plow.

In the first $30 \mathrm{~cm}$ the best degree of loosening was recorded on soils which had been plowed, where bulk density did not exceed $1.28 \mathrm{~g} / \mathrm{cm} 3$, and the lowest loosening on soils sown directly where the values ranged arownd $1.43 \mathrm{~g} / \mathrm{cm} 3$. In variants tilled with chisel and paraplow the bulk density values are practically equal 1.27-1.28 $\mathrm{g} / \mathrm{cm} 3$. Humus content on the $0-10 \mathrm{~cm}$ depth, between the four types of tillage, confirms in the case of direct seeding the highest values of 5.18\%, followed by the variant with paraplow of $5.11 \%$, $5.05 \%$ for chisel and lowest in the classical variant $4.89 \%$.

Taking into account the production potential of the land on which is cultivated, for winter wheat culture, using the variant with paraplow could be an alternative for the conventional plowed variant, knowing the advantages of conventional systems to reduce costs and especially those caused by the consumption of diesel.

Soil tillage system from variants with plowing respectively soil worked with chisel, paraplow and direct sowing ensures productions of soybean between $2310 \mathrm{~kg} / \mathrm{ha}$ in variant with plowing, 2142 $\mathrm{kg} / \mathrm{ha}$ for the variant with directly sowing and for the variants worked with chisel and paraplow productions between $2176-2234 \mathrm{~kg} / \mathrm{ha}$.

Comparing productions we notice a maximum amount of $6863 \mathrm{~kg} / \mathrm{ha}$ in the field where work was carried out using the plow at a depth of $28-30 \mathrm{~cm}$. We assign the explanation to the positive effects of the plowing on the growth regarding water conservation in soil, reducing the degree of weeds and favorising microorganisms activity by heating the soil early, in the growing season favouring a better vegetation starting of crops.

Tillage systems with chisel and paraplow recorded production of only $94.4-97.2 \%$ of the control variant with plow. The difference in minus 
at the variants with paraplow and chisel we primarily assign to the higher degree of weeds at the two ways of soil tillage.

After the economic analysis of the three variants it can be found that in the case of wheat crops is achieved a profit of $2-8 \%$ and one of $4-12 \%$ for soybean, this profit made per unit area is motivated since energy consumptions is more reduced to three modes of tillage.

For the maize crops the profits are lower in all three variants up to $8 \%$ as the number of plants per unit area is lower due to the uneven emergence.

In order to apply conservative solutions and techniques capable of halting the degradation and restoring of soil must be taken into account a number of issues on land suitability, structure of land use type, efficient technologies of cultivation and tillage to the implementation of pedologicalameliorative measures. An element which conditions the rational use of lands in the hilly areas and imposes technological restrictions is the slope of arable lands that is subjected to erosion.

\section{Acknowledgments.}

This paper was published under the frame of European Social Fund, Human Resources Development Operational Programme 2007-2013, project no. POSDRU/159/1.5/S/132765.

\section{REFERENCES}

1. Bogdan, I. (2003). Herbology, Print house Risporint, ClujNapoca.

2. Botta, G. F.; A . Tolon Becerra, F. Bellora (2009). Effect of the number of tractor passes on soil rut depth and compaction in two tillage regimes. Soil and Tillage Research, Amsterdam, v.103, p.381-386.

3. Bunescu, V., Gh., Mihai, H. Bunescu, I. Man (2005). Environmental conditions and soils in Transylvanian Plateau, Print house Academic Pres., Cluj Napoca

4. Caraqueo, G., J. Miguel, E. Acevedo, R. Rubio, P. Cornejo, F. Borie (2011). Effects of different tillage system on arbuscular mycorrhizal fungal propagules and physical properties in a Mediterranean agroecosystem in central Chile. Soil \& Tillage Research 113, p.11-18.

5. Feiza, V., I. Deveikyte and D. Simanskaite (2005). Soil physical and agrochemical properties changes, weediness and yield of crops in long-term tillage experiment in Lithuania. Scientific publication, vol. 48, Agronomy, USAMV Iasi.

6. Franchini, J.C., C.C. Crispino, R.A. Souza, E. Torres, M. Hungria (2007). Microbiological parameters as indicators of soil quality under various soil management and crop rotation systems in southern Brazil, Soil Tillage Research, nr. 92, p. 18-29.
7. Govaers, B., K.D. Sayre, J. Deckers (2005). Stable high yields wiyh zero tillage and permanent bed planting? Field Crop Research 94:33-42.

8. Gus, P., T. Rusu, I. Bogdan (2003). The conventional and unconventional soil tillage. Print house Risoprint, ClujNapoca.

9. Gus, P., T. Rusu, I. Bogdan (2004). Agrotechnique, Print house Risoprint, Cluj-Napoca.

10. Gus, P., T. Rusu, I. Bogdan (2004). Crop rotation and territory structure, Print house Risoprint Cluj-Napoca.

11. Horn, R., J.J.H. Van den Akker, J. Arvidsson (2000). Subsoil Compaction: Distribution, Processes and Consequences. Advances in GeoEcology 32, Catena Verlag, Reiskirchen Germany, 462.

12. Jitareanu G., C, Ailincai and D. Bucur (2006). Influence of tillage systems on soil physical and chemical caracteristics and yield in soybean and maize grown in the Moldavian Plain (North-Eastern Romania). In Soil Management for Sustainability, p. 370-379.

13. Lazureanu, A., D. Manea, Gh. Cârciu (1997). Influence of soil tillage and chemical fertilization on corn production, cultivated at Timisoara Didactic Station. In "Alternative Tillage"', vol.I, p. 23-30, Cluj-Napoca.

14. Licter, K., B. Govaerts, J. Six, K.D. Sayre,. J. Deckers, L. Dendooven (2008). Aggregation and C and N contents os soil organic matter fractions in a permanent raised bed planting system in the Highlands of Central Mexico. Plant Soil 305:237-252.

15. Mark, A., M. Al-Kaisi (2004). Strip-tillage effect seedbed soil temperature and other soil physical properties. Soil and Tillage Research, Volume 80, ISSUES 1-2, 233-249.

16. Martinez, E., J.P. Fuentes, P. Silva, S. Valle, E. Acevedo (2008). Soil physical properties and wheat root growth as affected by no-tillage and conventional tillage systems in a Mediterranean environment of Chile. Soil Tillage Research. 99, 232-244.

17. Moroizumi T., H. Horino (2002). The effects of tillage on soil temperature and soil water. Soil Science 167:548-559.

18. Pop, A. I. (2009). Establishing the influence of soil works and crop rotation upon soil, production and profit in the Somes plateau, Phd Thesis, USAMV Library, Cluj-Napoca.

19. Pop, A.I., P. Gus, T. Rusu, I. Bogdan, P. I. Moraru (2013). The economic efficiency of the soybean culture depending on the soil tilling system and the pre-emerging plant, The 7 th International Symposium „Soil Minimum Tillage Systems”, Cluj-Napoca, 2-3 May 2013, Journal of Documentation, Research and Professional Training, ProEnvironment Vol. 6, No. 14 April 2013, Print ISSN: 1844-6698, Electronic ISSN: 2066-1363, p.171-174.

20. Pop, Gr. (2001). Transylvanian Depression, Print house Cluj University Press, Cluj - Napoca

21. Roscoe, R., P. Buurman (2003). Tillage effects on soil organic matter in density fractions of a Cerrado Oxisol, Soil Tillage Research 70, 107-119.

22. Rusu, T. (1998). The difference between soil tillage for the protection against soil erosion in the colinary region of Cluj-Napoca, Paper presented at the national symposium 
"Economical researches and studies", vol. XXVIII-XXIX, page 1305-1312, Cluj-Napoca

23. Rusu, T. (2001). The influence of Minimum Soil Tillage upon the soil yield and efficiency. PhD Thesis, University of Agricultural Sciences and Veterinary Medicine of ClujNapoca.

24. Rusu, T., P. Gus, I. Bogdan, P. I. Moraru, A. I. Pop, D. Clapa, D. I. Marin, I. Oroian, and L.I Pop (2009). Implications of minimum tillage systems on sustainability of agricultural production and soil conservation. Journal of Food, Agriculture \& Environment, vol. 7(2): 335-338. 2009, Print ISSN: 1459-0255, WFL Publisher Science and Technology, Helsinki, Finlanda. Online Journal JFAE, vol. 7 (2/2009) www.world-food.net., Section Environment, Online ISSN: 1459-0263. http://www.world-food.net/ scientificjournal.php, p. 335-338.

25. Rusu, T., P.I. Moraru, O. Ranta, I. Drocaș, I. Bogdan, A. I. Pop and M. L. Şopterean (2011). No-tillage and minimum tillage-their impact on soil compaction, water dynamics, soil temperature and production on wheat, maize and soybean crop, In Bulletin of USAMV ClujNapoca Agriculture, 68(1)/2011, print ISSN 1843-5246, Electronic ISSN 1843-5386, 318-323.

26. Rusu, T, I Bogdan, A.I. Pop (2012). Indrumator de lucrari practice la Agrotehnica, Editura Grinta Cluj-Napoca.

27. Sarauskis, E., E. Vaiciukevicius, K. Romaneckas, A Sakalauskas and R. Baranauskaite (2009). Economic and energetic evaluation of sustainable tillage and cereal sowing technologies in Lithuania. Rural Development 4 (1), p.280-285.
28. Sayre, K.D., A.O. Limon, B. Govaerts (2007). Experiences with permanent bed planting systems. CIMMYT, Mexico. Evolution and Performance of Permanent raised Bed Cropping Sysyems in Asia, Australia and Mexico proceeding of Workshop: 12-25.

29. Săndoiu, I.D. (1999). Problems regarding introducing of alternative soil tillage in Romanian Plateau, International Symposion, 'Minimum soil tillage systems', UASMV Cluj, Faculty of Agriculture, 21 - 22th of October 1999, ClujNapoca.

30. Teixeira, L.G., A. Lopes and N. Scala (2010). Temporal variability of soil $\mathrm{CO}_{2}$ emission after conventional and reduced tillage described by an exponential decay in time model. Eng. Agric. Vol. 30. no 2. Saboticabal Mar./Apr. 2010.

31. Ulrich, S., B. Hofmann, S. Tischer and. O. Christen (2006). Influence of Tillage on Soil Quality in a Long Term Trial in Germany. In Soil Management for Sustainability, 110-116.

32. Polifact (2002). ANOVA and Duncan's test pc program for variant analyses made for completely randomized polifactorial experiences. USAMV Cluj-Napoca.

33. SRTS (2003). Romanian System of Soil Taxonomy. Ed. Estfalia, Bucharest, p.182.

34.*** (2004). The ethics of sustainable agricultural intensification, FAO Ethics Series, ISBN 92-5-105067-8.

35. *** Geography of Romania, vol. III (1987). Romanian Carpathians and Transylvanian Depression, Print house Socialist Republic of Romania. 